\title{
Strontium potently inhibits mineralisation in bone-forming primary rat osteoblast cultures and reduces numbers of osteoclasts in mouse marrow cultures
}

\author{
D. P. Wornham • M. O. Hajjawi • I. R. Orriss • \\ T. R. Arnett
}

Received: 30 April 2014 / Accepted: 20 June 2014 / Published online: 22 July 2014

(C) The Author(s) 2014. This article is published with open access at Springerlink.com

\begin{abstract}
Summary The basic mechanisms by which strontium ranelate acts on bone are still unclear. We show that an important action of strontium salts is to block calcification in cultures of osteoblasts, the bone-forming cells. These results suggest that strontium treatment could have previously overlooked effects on bone.

Introduction The basic mechanisms of action of strontium ranelate $(\mathrm{SrR})$ on bone have remained unclear. We studied the direct actions of $\mathrm{Sr}^{2+}$ salts in functional cultures of osteoblasts and osteoclasts.

Methods Cultures of primary osteoblasts from rat calvariae and osteoclast-forming mouse marrow cells were treated continuously with either SrR or strontium chloride $\left(\mathrm{SrCl}_{2}\right)$.

Results Abundant, discretely mineralised 'trabecular' bone structures formed in control osteoblast cultures after 14 days. SrR at $0.01,0.1$ and $1 \mathrm{mM}$ inhibited mineralisation to 59,98 and $100 \%$ (all $p<0.001$ ) of control values, respectively. $\mathrm{SrCl}_{2}$ at the same concentrations caused similar inhibitions. Osteoblast cell numbers and alkaline phosphatase activity were unaltered. SrR dose-dependently reduced the formation of multinucleated osteoclasts from marrow mononuclear cells cultured on dentine for 8 days in the presence of macrophage colony-stimulating factor (M-CSF) and receptor activator of nuclear factor kappa B ligand (RANKL), with a $50 \%$ inhibition occurring at $1 \mathrm{mM} ; \mathrm{SrCl}_{2}$ was slightly less effective, eliciting a maximal $30 \%$ inhibition. Corresponding decreases in total resorption pit formation were observed, suggesting
\end{abstract}

D. P. Wornham • M. O. Hajjawi • I. R. Orriss • T. R. Arnett $(\triangle)$ Department of Cell and Developmental Biology, University College London, Gower Street, London WC1E 6BT, UK

e-mail: t.arnett@ucl.ac.uk

I. R. Orriss

Royal Veterinary College, Royal College Street, London NW1 0TU, UK
$\mathrm{Sr}^{2+}$ salts affect osteoclast formation rather than resorptive activity.

Conclusion Our findings are consistent with the documented physicochemical inhibitory action of $\mathrm{Sr}^{2+}$ on mineralisation but contrast with reports that $\mathrm{Sr}^{2+}$ increases osteoblast activity and number in vitro. Our results suggest that rather than acting as an agent that 'uncouples' bone formation and resorption, $\mathrm{Sr}^{2+}$ acts as a global inhibitor of bone cell function, with particularly marked effects on mineralisation. The potential effects of long-term $\mathrm{Sr}^{2+}$ on secondary mineralisation in bone deserve investigation.

Keywords Bone cells $\cdot$ Calcification $\cdot$ In vitro $\cdot$ Mineral solubility $\cdot$ Ranelate

\section{Introduction}

The protective properties of strontium salts on bone were first suggested in 1959 when strontium lactate was reported to decrease bone pain in a small study of osteoporotic patients and increase bone density radiographically [1]. Following the report that strontium ranelate reduced vertebral fracture in osteoporotic postmenopausal women, it has been widely used in the treatment of osteoporosis. While the anti-fracture efficacy of strontium has been well established $[2,3]$, the fundamental ways in which it acts on bone components remain unclear.

Following the observation that dietary supplementation with strontium chloride increased osteoid surface and decreased osteoclast numbers in mice [4], the notion that strontium can act as a direct 'uncoupler' of bone turnover, enhancing bone formation and decreasing resorption, has become well established [5-7]. Studies with cultured primary cells indicated that strontium increased the proliferation of preosteoblasts [8] and also osteoblast differentiation and 
mineralisation $[7,9,10]$. Activation of the calcium-sensing receptor is reported to be a key pathway mediating beneficial actions of strontium on osteoblasts, such as increased proliferation $[11,12]$, inhibition of prostaglandin-mediated apoptosis [12] and increased nuclear translocation of $\beta$-catenin [13]. Strontium is also reported to increase Wnt signalling in osteoblasts [10] and to promote osteoblastogenesis through nuclear factor kappa B (NF-kB) blockade [14]. Strontium may reduce osteoclast activity by disrupting ruffled border formation [15] or the 'sealing zone' substrate contact [7]. Strontium is additionally reported to reduce osteoclast formation [7] and may cause osteoclast apoptosis via an NF-kB-mediated pathway, albeit at very high concentrations $[16,17]$.

Strontium has also long been known to exert physicochemical effects on hydroxyapatite mineral, increasing its solubility [18-20]. Moreover, strontium causes osteomalacia in a rat model of chronic renal failure [21] and is associated with osteomalacia in dialysis patients [22]. In normal monkeys, however, strontium treatment was reported to have no significant effect on bone mineral [23].

In view of the continuing debate over the actions of strontium on bone and the lack of congruent studies that have assessed the direct effects of strontium on the ultimate physiological functions of osteoblasts and osteoclasts, namely bone formation and mineralised tissue resorption, we performed the present investigation. The primary aims of this study were to determine the effects of physiologically relevant concentrations of strontium salts on (1) the formation and mineralisation of bony structures ('nodules') in primary cultures of rat osteoblasts and (2) the formation and resorptive activity of osteoclasts in mouse marrow cultures.

\section{Materials and methods}

\section{Reagents}

Dulbecco's modified Eagle's medium and foetal calf serum were purchased from (Gibco, Paisley, UK); macrophage colony-stimulating factor (M-CSF), receptor activator of NF- $\mathrm{kB}$ ligand (RANKL) and prostaglandin $\mathrm{E}_{2}$ were from R\&D Systems Europe (Abingdon, UK). Other reagents were from Sigma-Aldrich (Poole, UK), except where otherwise stated.

\section{Primary osteoblast culture}

Bone-forming, primary rat osteoblastic cells were obtained by sequential enzyme digestion of excised calvarial bones from 2-day-old neonatal Sprague Dawley rats using a three-step process, as previously described [24, 25]. Briefly, bones were treated with $1 \%$ trypsin in phosphate-buffered saline (PBS) for $10 \mathrm{~min}, 0.2 \%$ collagenase type II in Hank's balanced salt solution (HBSS) for $30 \mathrm{~min}$, then $0.2 \%$ collagenase type II in HBSS for $60 \mathrm{~min}$. The first two digests were discarded and the cells from the final digest resuspended in Dulbecco's modified essential medium supplemented with $10 \%$ foetal calf serum (FCS), $2 \mathrm{mML}$-glutamine, $100 \mathrm{U} / \mathrm{ml}$ penicillin, $100 \mu \mathrm{g} / \mathrm{ml}$ streptomycin and $0.25 \mu \mathrm{g} / \mathrm{ml}$ amphotericin (complete mixture abbreviated to 'DMEM'). Cells were cultured for 2-4 days in a humidified atmosphere of $5 \% \mathrm{CO}_{2}-95 \%$ air at $37^{\circ} \mathrm{C}$ in 75 $\mathrm{cm}^{2}$ flasks until confluent. Upon confluence, cells were subcultured into multiwell plates in 'supplemented' DMEM containing dexamethasone $(10 \mathrm{nM}), \beta$-glycerophosphate $(2 \mathrm{mM})$ and ascorbate $(50 \mu \mathrm{g} / \mathrm{ml})$. Cells were then cultured for 14 days in the absence or presence of $1 \mu \mathrm{m}-1 \mathrm{mM}$ strontium chloride or ranelate, with half medium changes every 3 days. Medium $\mathrm{pH}, \mathrm{pO}_{2}$ and $\mathrm{pCO}_{2}$ were controlled throughout.

At 14 days, cell layers were fixed in $2 \%$ glutaraldehyde for $5 \mathrm{~min}$ and washed with $70 \%$ ethanol prior to drying. Plates were imaged at 2,000 dots $/ \mathrm{cm}^{2}$ using a high-resolution flatbed scanner (Perfection Photo 3200; Epson UK, Hemel Hempstead, UK). Binary images of each well were analysed using constant threshold and minimum particle levels (ImageJ software, National Institutes of Health), allowing measurement of the numbers bone nodules formed and their plan surface area.

Primary osteoclast culture

Osteoclast-forming marrow mononuclear cells were obtained by flushing the long bones of two 6-8-week-old MF1 mice using a 25-gauge needle, as previously described [26]. After washing in PBS, marrow cells were initially cultured for $24 \mathrm{~h}$ at $37{ }^{\circ} \mathrm{C}$ in $5 \% \mathrm{CO}_{2}$ in $75-\mathrm{cm}^{2}$ flasks in minimal essential medium (MEM) supplemented with $10 \%$ FCS, 2 mMLglutamine, $100 \mathrm{U} / \mathrm{ml}$ penicillin, $100 \mu \mathrm{g} / \mathrm{ml}$ streptomycin, $0.25 \mu \mathrm{g} / \mathrm{ml}$ amphotericin $\mathrm{B}$ and $100 \mathrm{nM}$ prostaglandin $\mathrm{E}_{2}$ $\left(\mathrm{PGE}_{2}\right)$ (abbreviated 'supplemented MEM') containing $2.5 \mathrm{ng} / \mathrm{ml} \mathrm{M-CSF}$. Non-adherent cells were collected and resuspended at $5 \times 10^{6}$ cells $/ \mathrm{ml}$ in supplemented MEM containing $10 \mathrm{ng} / \mathrm{ml} \mathrm{M-CSF}$ and $3 \mathrm{ng} / \mathrm{ml}$ RANKL. Two-hundredmicrolitre samples of cell suspension $\left(10^{6}\right.$ cells $)$ were allowed to sediment for $24 \mathrm{~h}$ onto 5 -mm-diameter dentine discs (elephant ivory kindly donated by HM Revenue and Customs, Heathrow Airport, UK) in 96 -well trays at $37^{\circ} \mathrm{C}$ to allow the attachment of osteoclast precursors. Dentine discs were then transferred to six-well trays containing supplemented MEM with $10 \mathrm{ng} / \mathrm{ml} \mathrm{M-CSF}$ and $3 \mathrm{ng} / \mathrm{ml}$ RANKL. Cells were cultured for 8 days in $5 \% \mathrm{CO}_{2}$ with $0-1 \mathrm{mM}$ of strontium ranelate or chloride. For the final 2 days of culture, the medium $\mathrm{pH}$ was reduced from 7.4 to 7.0 by addition of $\mathrm{HCl}$ in order to activate resorption pit formation by mature osteoclasts formed.

Experiments were terminated by washing discs in PBS followed by fixation in $2.5 \%$ glutaraldehyde for $5 \mathrm{~min}$. Discs 
were stained for tartrate-resistant acid phosphatase (TRAP) using a leucocyte acid phosphatase kit. Osteoclasts were identified as TRAP-positive multinucleated cells; numbers of osteoclasts, area resorbed and, thus, activity per osteoclast were evaluated blindly using transmitted and reflected light microscopy, respectively, on coded discs, as described previously [26].

\section{Determination of alkaline phosphatase activity}

Osteoblast alkaline phosphatase activity was measured in cell lysates after 4, 7, 10 and 14 days in culture using a colorimetric kit, as previously described [24].

Cell number and viability assay

Cell numbers were measured at 3, 7,10 and 14 days after seeding osteoblasts at $2.5 \times 10^{4}$ cells/well into 24 -well plates, using a colorimetric kit (CytoTox 96 ${ }^{\circledR}$; Promega UK, Southampton, UK) which quantifies cellular lactate dehydrogenase (LDH) activity, as previously described [27]. Briefly, cells were lysed with $1 \%$ Triton X-100 in water (lysis buffer, $15 \mu \mathrm{l} / \mathrm{ml}$ of medium) for $1 \mathrm{~h}$. The culture medium supernatant and cell lysate LDH content were measured independently (ELx800 plate reader; BioTek International) according to the manufacturer's instructions, using a standard curve derived from cells seeded between $10^{2}$ and $10^{6} /$ well. Cell viability was estimated as the ratio of total cellular LDH to culture medium LDH.

Ionised $\mathrm{Ca}^{2+}$ and $\mathrm{pH}$ assessment

Ionised calcium and $\mathrm{pH}$ were measured in $300-\mu \mathrm{l}$ medium samples of culture medium using a blood gas analyser (Radiometer 705; Radiometer, Crawley, UK).

Statistical analysis

Experimental data were analysed using one-way ANOVA using the Bonferroni method to correct for multiple comparisons. Results are presented as the mean \pm standard error of the mean (SEM) for six replicates.

\section{Results}

Strontium salts inhibit bone mineralisation in vitro

Control cultures of rat osteoblasts formed abundant nodules and trabecula-like structures of mineralised bone matrix after 14 days. Strontium ranelate $(\mathrm{SrR})$ reproducibly caused a strong, dose-dependent inhibition of mineralisation, with near-total blockade observed at a concentration of $0.1 \mathrm{mM}$. However, production of collagenous matrix structures appeared to be unaffected even in the presence of the highest concentration of strontium ranelate used $(1 \mathrm{mM})$ (Fig. 1). At concentrations of 0.01, 0.1 and $1 \mathrm{mM}$, SrR elicited 59, 98 and $100 \%$ inhibitions of mineralisation of control values, respectively. Strontium chloride $\left(\mathrm{SrCl}_{2}\right)$ also inhibited mineralisation strongly, causing 34,95 and $100 \%$ reductions at the same concentrations (Fig. 2a). Strontium salts caused a corresponding increase in the retention of ionised calcium in the osteoblast culture medium. After 14 days of treatment with $1 \mathrm{mM}$ $\mathrm{SrR}$ or $\mathrm{SrCl}_{2}$, the measured calcium concentration in the culture medium was the same as that in the medium from undifferentiated day 3 cultures in which the control osteoblasts had yet to begin mineralising (i.e. about $1 \mathrm{mM}$ ). Medium $\mathrm{pH}$ in strontium-treated cultures remained close to the control value (Fig. 2b).

A moderate reduction of osteoblast alkaline phosphatase (ALP) activity was observed in 14-day cultures treated with $\mathrm{SrCl}_{2}$; smaller decreases were also seen in SrR-treated cultures (Fig. 3a). In parallel, strontium salts caused increases in lactate dehydrogenase release from cells, an index of cell morbidity/ mortality, although estimated cell numbers were not significantly affected (Fig. 3b).

Strontium salts inhibit osteoclast numbers and resorption pit formation

Continuous treatment with strontium salts caused reductions of up to about $50 \%$ in the total surface area of resorption pits and in the numbers of multinucleated osteoclasts present on ivory discs in 8-day cultures of mouse marrow cells. However, the area resorbed by individual osteoclasts was not significantly reduced (Figs. 4 and 5).

\section{Discussion}

Strontium ranelate has been regarded as an anti-osteoporotic drug that can shift the balance between bone resorption and bone formation towards the latter. However, the mechanisms by which strontium exerts its effects on bone have remained relatively unclear [28]. Our results clearly demonstrate that strontium salts have two direct effects on bone cell function in vitro. Their major action is to cause potent inhibition of mineral deposition in bone-forming cultures of primary osteoblasts. Secondly, strontium salts cause moderate reductions in osteoclast numbers and, thus, resorption pit formation in mouse marrow cultures on dentine surfaces.

Mineralisation in bone-forming osteoblast cultures was dose-dependently reduced by strontium salts, with partial or near-complete inhibition at 0.01 and $0.1 \mathrm{mM}$, respectively. 
Fig. 1 Strontium ranelate $(\mathrm{SrR})$ blocks bone matrix mineralisation in 14-day primary cultures of rat osteoblasts. Upper row images are reflected light scans of unstained cell wells; mineralised bone nodules appear as white features; scale bar $=0.5 \mathrm{~cm}$. Lower row images are corresponding phase contrast (transmitted light) micrographs of unstained cell layers; mineralised bone nodules appear as black features, and unmineralised collagenous matrix is white-grey; scale bar $=0.5 \mathrm{~mm}$
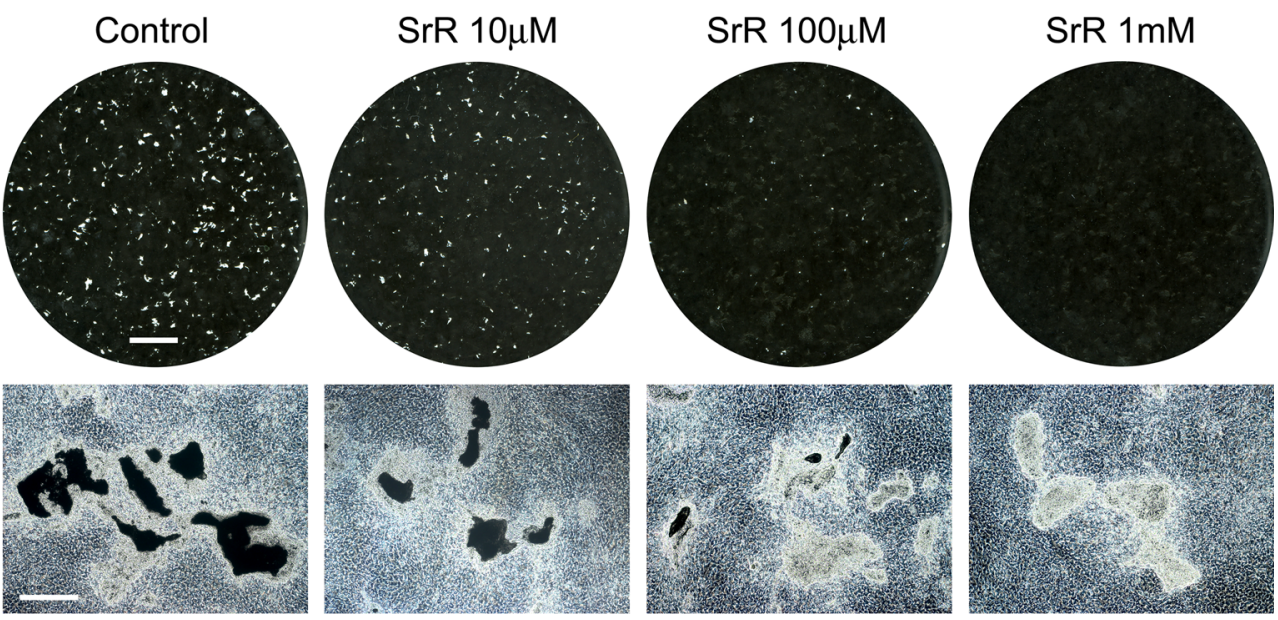

The strontium-treated cultures showed a striking and corresponding increase in the presence of unmineralised matrix nodules. The observed inhibition of mineralisation by strontium salts at micromolar concentrations in primary rat osteoblast cultures is in broad agreement with the earlier findings of Verberckmoes et al. [29]. We also failed to observe
Fig. 2 a Dose-dependent inhibition of mineralised bone formation in 14-day rat osteoblast cultures by strontium salts. Strontium ranelate $(\mathrm{SrR})$ caused near-total blockade at concentrations $\geq 0.1 \mathrm{mM}$; strontium chloride $\left(\mathrm{SrCl}_{2}\right)$ completely blocked

mineralisation at a concentration of $1 \mathrm{mM}$. b Strontium salts caused a corresponding increase in the retention of ionised calcium in the culture medium of bone-forming osteoblasts; the measured concentration of ionised $\mathrm{Ca}^{2+}$ in the culture medium at day 3 (i.e. before onset of osteoblast differentiation and mineral deposition) was $1.03 \mathrm{mM}$. Culture medium $\mathrm{pH}$ remained within 0.01 unit of the control value. $\mathrm{pH}$ was corrected for $\mathrm{CO}_{2}$ concentration. Data are means \pm SEM for six replicate determinations; ${ }^{* * *} p<0.001$, significantly different from control
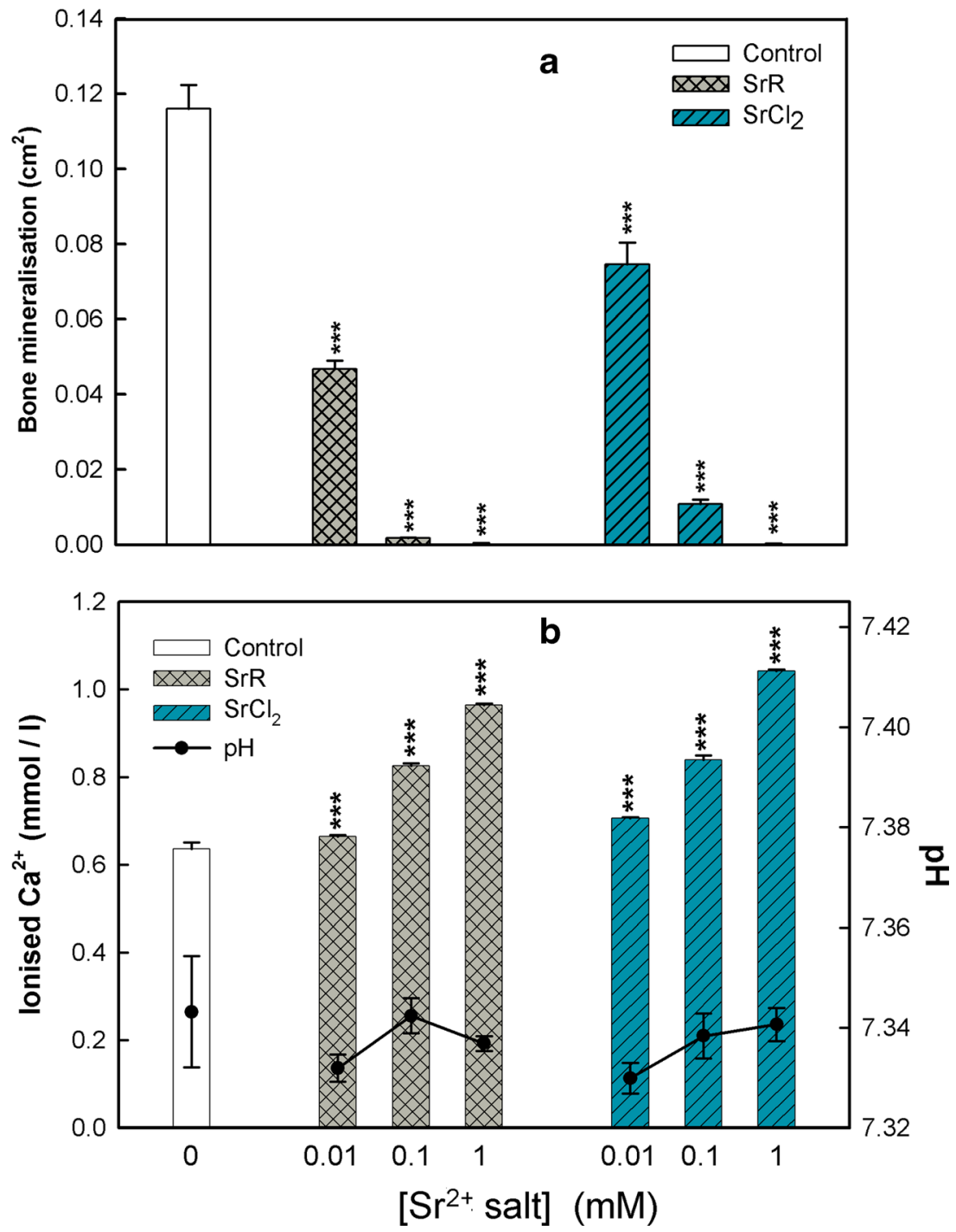
Fig. 3 a Effect of strontium salts on alkaline phosphatase (ALP) activity in 14-day rat osteoblast cultures: modest inhibition by $\mathrm{SrCl}_{2}$. b Strontium salts were also associated with moderate decreases in cell viability, assessed as lactate dehydrogenase activity, although cell numbers were not affected. Data are means \pm SEM for six replicate determinations; ${ }^{*} p<0.05$; $* * p<0.01 ; * * * p<0.001$, significantly different from control
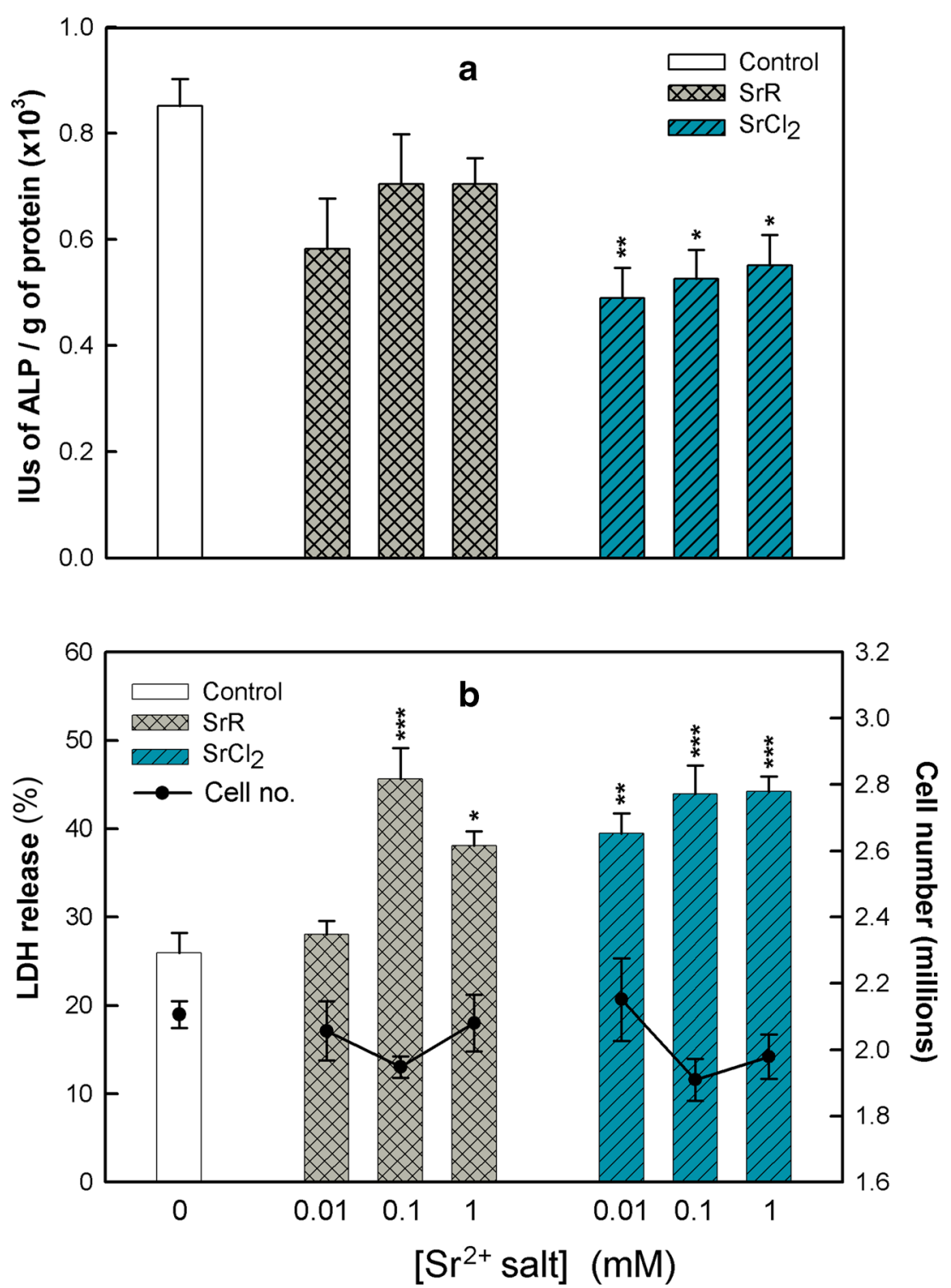

any clear-cut effect of strontium on osteoblast numbers (although an apparent reduction in cell viability was noted in strontium-treated cultures). In contrast, we found a modest inhibitory effect of strontium chloride at submillimolar concentrations on osteoblast alkaline phosphatase activity. These findings are at variance with those of several other studies on the action of strontium ranelate in calvarial osteoblast cultures. Acute stimulation of proliferation of rat osteoblasts was described following exposure to high concentrations (1-5 mM) of SrR [8, 11]. Increased calcification and expression of
Fig. 4 Strontium ranelate causes a moderate inhibition of numbers of multinucleated osteoclasts observed in mouse marrow mononuclear cells cultured for 8 days on ivory discs with M-CSF and RANKL. TRAP-stained preparation; resorption pits are visible as tan areas associated with osteoclasts. Scale bar $=$ $100 \mu \mathrm{m}$
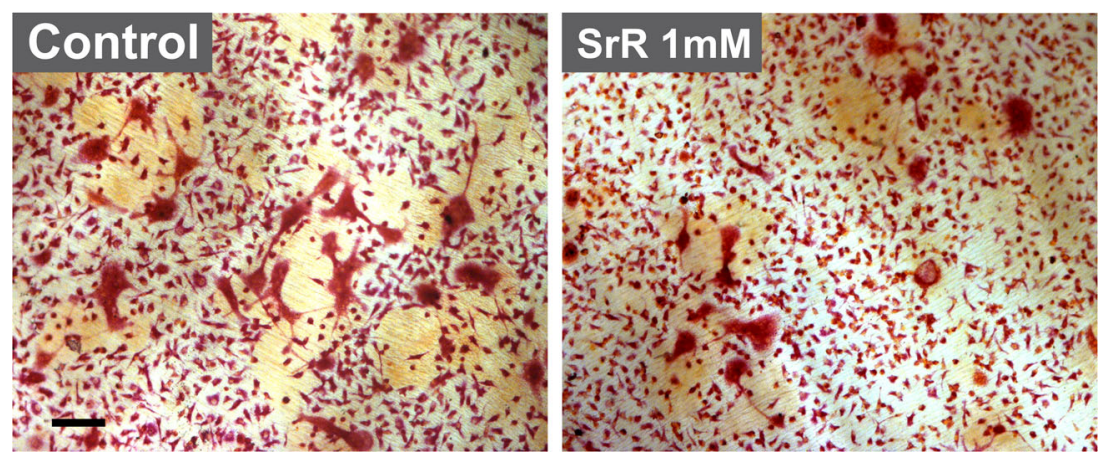

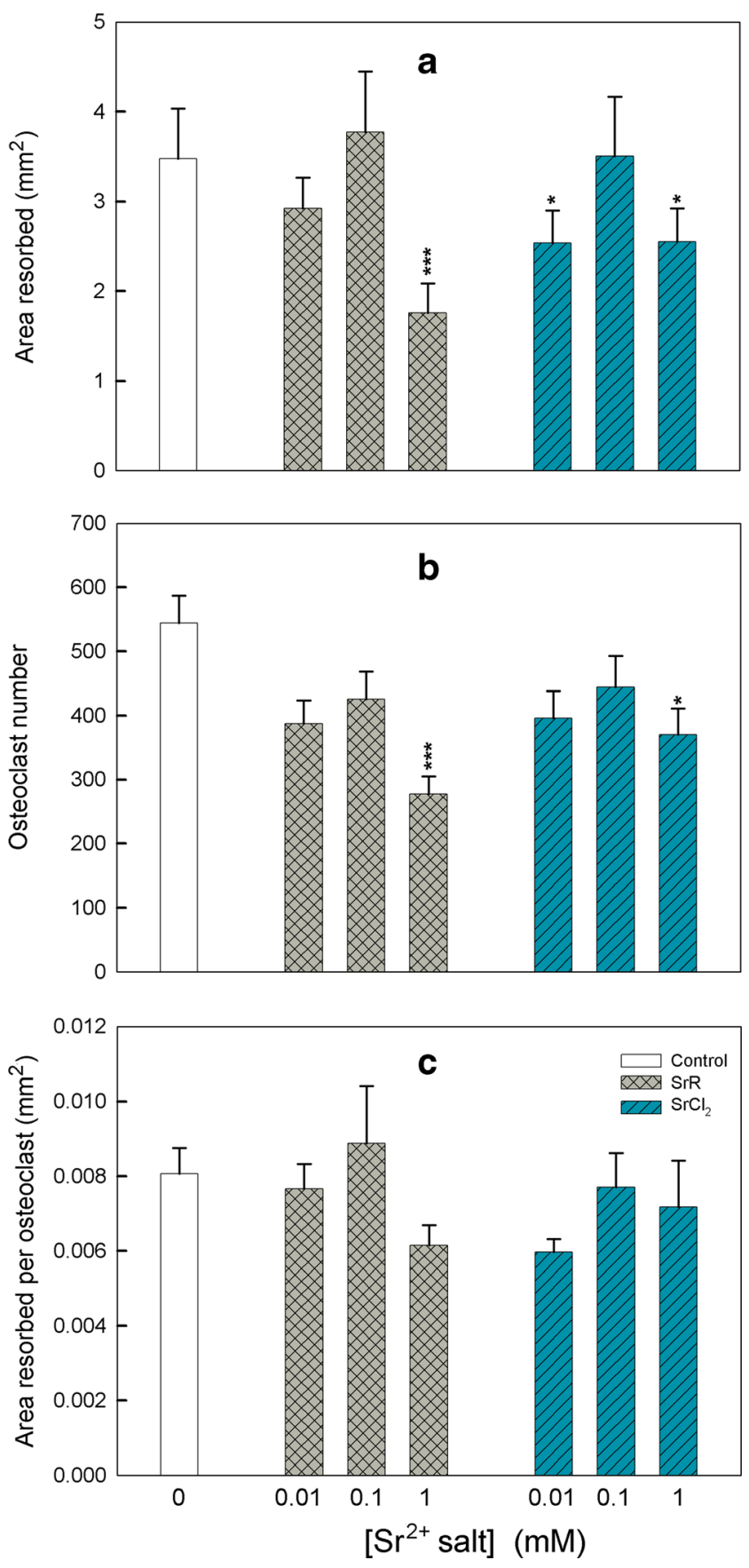

Fig. 5 a Strontium salts cause a moderate inhibition of resorption pit formation by osteoclasts generated in 8-day cultures of mouse marrow cells on ivory discs. b Strontium salts were associated with corresponding decreases in numbers of multinucleated, TRAP-stained osteoclasts. $\mathbf{c}$ The resorptive activity of individual osteoclasts was not affected by strontium salts. Data are means $\pm \mathrm{SEM}$ for eight replicate determinations; ${ }^{*} p<0.05$; $* * * p<0.001$, significantly different from control

alkaline phosphatase mRNA were reported for mouse osteoblasts treated chronically with $0.1-1 \mathrm{mM}$ strontium ranelate [7]. In the MC3T3-E1 cell line, however, strontium ranelate treatment increased the strontium content of deposited mineral but failed to increase calcification [30]. The discrepancies between the above findings could, to some extent, be accounted for by significant differences in osteoblast culture methods. The key advantage of the culture system employed in the present study is the formation of abundant bony structures that resemble trabeculae, with clearly distinguished mineralised and non-mineralised components [24, 25].

Our study showed that strontium ranelate was a significantly more effective inhibitor of mineralisation on a molar basis than strontium chloride. This discrepancy in potency may well be due to the differing stoichiometry of these two strontium salts. Ranelate chelates two strontium ions per molecule, whereas the chloride salt has only a single strontium ion. However, it is possible that the ranelate component of strontium ranelate may also have an independent calcium ionchelating action that could affect mineralisation. The inhibition of mineralisation in strontium-treated osteoblast cultures was reflected in increased retention of ionised calcium in the culture medium. It should be noted that this calcium retention was of a lower relative magnitude than the degree of inhibition of mineralisation. This apparent inconsistency is explained by the changes of culture medium that were made every 3-4 days. Studies by Verberckmoes et al. [31], using mineralising cultures of osteoblast-like UMR-106 cells and synthetic calcium hydroxyapatite doped with increasing concentrations of strontium, have suggested that strontium inhibits mineralisation via two physicochemical effects: first, direct inhibition of crystal growth and, secondly, increased solubility of calcium hydroxyapatite.

The action of strontium salts on osteoclast function was much less marked than on osteoblasts and mineralisation. At the highest concentration tested ( $1 \mathrm{mM})$, strontium caused 33 $50 \%$ reductions in both osteoclast numbers and resorption pit formation, suggesting that it had little or no direct effect on osteoclast activity (i.e. resorption pit formation). The reduced numbers of osteoclasts observed in strontium-treated cultures could be due either to reduced formation or reduced survival or both. Previous studies have noted reductions in osteoclast numbers in cultures treated with strontium salts at concentrations up to $24 \mathrm{mM}[7,17]$; these very high concentrations are well outside the in vivo range, however.

The strontium concentrations used in the present study spanned the levels measured in the blood of treated individuals $(0.02 \mathrm{mM})$ [32]. However, there is a clear discrepancy between our in vitro findings and the results of the major clinical trials of strontium ranelate, which showed decreased fracture risk associated with increases in bone mineral density of between 7.2 and $14.4 \%$ after prolonged treatment $[2,33]$. It should be noted, though, that a significant component of the increased bone mineral density measured in strontium-treated patients could be due to the incorporation of strontium, which has more than twice the atomic mass of calcium; a $1 \%$ molar concentration of strontium has been shown to cause a $10 \%$ overestimation of BMD [34]. In contrast to the reported 
increases in bone mineral density, strontium-induced osteomalacia has been described in rats with chronic renal failure $[21,35]$. Strontium levels in blood and bone have been linked to osteomalacia in human patients undergoing haemodialysis in some studies $[22,36]$.

The key limitation of our study is that it was conducted in vitro using rodent cells. However, cell or organ cultures represent the only practicable way to study the direct effects of strontium on bone cells, free of the confounding influences present in vivo. The use of rodent osteoblasts was necessitated because primary human osteoblasts (at least from adults) have not been shown to be capable of true bone formation in vitro. Clearly, caution is needed when relating tissue culture results to the in vivo situation. Nevertheless, our findings do suggest a number of testable ideas. The first is that long-term strontium treatment might act to reduce fracture risk because it could reduce the secondary hypermineralisation that occurs in low-turnover bone, thus decreasing stiffness and reducing brittleness [37]. Similarly, strontium treatment, which is reported to be protective against some forms of osteoarthritis $[38,39]$, might act to reduce secondary mineralisation of subchondral bone, making it less stiff. It is also conceivable that strontium could affect the progression of the tidemark zone of mineralisation in articular cartilage. A further possibility is that strontium treatment might act to modulate the infilling of osteocyte lacunae resulting from hypermineralisation [40].

Widespread use of strontium ranelate has now been discontinued in most countries, following recent recommendations concerning its potential cardiovascular risk, although this remains somewhat controversial [41]. It is nonetheless important that the mechanisms of action of strontium on bone are better understood - not only for patients already treated but also because new therapeutic directions could be suggested, particularly with regard to the control of mineralisation.

\section{Conflicts of interest None.}

Open Access This article is distributed under the terms of the Creative Commons Attribution Noncommercial License which permits any noncommercial use, distribution, and reproduction in any medium, provided the original author(s) and the source are credited.

\section{References}

1. McCaslin FE, Janes JM (1959) The effect of strontium lactate in the treatment of osteoporosis. Proc Staff Meetings Mayo Clin 34:329334

2. Reginster JY, Seeman E, De Vernejoul MC, Adami S, Compston J, Phenekos C, Devogelaer JP, Diaz Curiel M, Sawicki A, Goemaere S, Sorensen OH, Felsenberg D, Meunier PJ (2005) Strontium ranelate reduces the risk of nonvertebral fractures in postmenopausal women with osteoporosis: Treatment of Peripheral Osteoporosis (TROPOS) study. J Clin Endocrinol Metab 90:2816-2822

3. Roux C, Fechtenbaum J, Kolta S, Isaia G, Andia JB, Devodelaer JP (2008) Strontium ranelate reduces the risk of vertebral fracture in young postmenopausal women with severe osteoporosis. Ann Rheum Dis 67:1736-1738

4. Marie PJ, Hott M (1986) Short-term effects of fluoride and strontium on bone formation and resorption in the mouse. Metabolism 35:547551

5. Marie PJ, Hott M, Modrowski D, de Pollak C, Guillemain J, Deloffre P, Tsouderos Y (1993) An uncoupling agent containing strontium prevents bone loss by depressing bone resorption and maintaining bone formation in estrogen-deficient rats. J Bone Min Res 3:607-615

6. Ammann P (2006) Strontium ranelate: a physiological approach for an improved bone quality. Bone 38:15-18

7. Bonnelye E, Chabadel A, Saltel F, Jurdic P (2008) Dual effect of strontium ranelate: stimulation of osteoblast differentiation and inhibition of osteoclast formation and resorption in vitro. Bone 42:129138

8. Canalis E, Hott M, Deloffre P, Tsouderos Y, Marie PJ (1996) The divalent strontium salt S12911 enhances bone cell replication and bone formation in vitro. Bone 18:517-523

9. Marie PJ (2005) Strontium ranelate: a novel mode of action optimizing bone formation and resorption. Osteoporos Int 16:S7-S10

10. Yang F, Yang D, Tu J, Zheng Q, Cai L, Wang L (2011) Strontium enhances osteogenic differentiation of mesenchymal stem cells and in vivo bone formation by activating Wnt/catenin signalling. Stem Cells 29:981-991

11. Chattopadhyay N, Quinn SJ, Kifor O, Ye C, Brown EM (2007) The calcium-sensing receptor $(\mathrm{CaR})$ is involved in strontium ranelateinduced osteoblast proliferation. Biochem Pharmacol 74:438-447

12. Fromigue O, Hay E, Barbara A, Petrel C, Traiffort E, Ruat M, Marie PJ (2009) Calcium sensing receptor-dependent and receptorindependent activation of osteoblast replication and survival by strontium ranelate. J Cell Mol Med 13:2189-2199

13. Rybchyn MS, Slater M, Conigrave AD, Mason RS (2011) An Aktdependent increase in canonical Wnt signaling and a decrease in sclerostin protein levels are involved in strontium ranelate-induced osteogenic effects in human osteoblasts. J Biol Chem 286:2377123779

14. Yamaguchi M, Weitzmann MN (2012) The intact strontium ranelate complex stimulates osteoblastogenesis and suppresses osteoclastogenesis by antagonizing NF-kB activation. Mol Cell Biochem 359: 399-407

15. Takahashi N, Sasaki T, Tsouderos Y, Suda T (2003) S 12911-2 inhibits osteoclastic bone resorption in vitro. J Bone Min Res 18: 1082-1088

16. Hurtel-Lemaire AS, Mentaverri R, Caudrillier A, Cournarie F, Wattel A, Kamel S, Terwilliger EF, Brown EM, Brazier M (2008) The calcium-sensing receptor is involved in strontium ranelate-induced osteoclast apoptosis: new insights into the associated signalling pathways. J Biol Chem 284:575-584

17. Caudrillier A, Hurtel-Lemaire AS, Wattel A, Cournarie F, Godin C, Petit L, Petit JP, Terwilliger E, Kamel S, Brown EM, Mentaverri R, Brazier M (2010) Strontium ranelate decreases receptor activator of nuclear factor-B ligand-induced osteoclastic differentiation in vitro: involvement of the calcium-sensing receptor. Mol Pharm 78:569576

18. Grynpas M (1993) Age and diseases-related changes in the mineral of bone. Calcif Tissue Int 53:S57-64

19. Christoffersen J, Christoffersen MR, Kolthoff N, Barenholdt O (1997) Effects of strontium ions on growth and dissolution of hydroxyapatite and on bone mineral detection. Bone 20:47-54

20. Pan HB, Li ZY, Lam WM, Wong JC, Darvell BW, Luk KDK, Lu WW (2009) Solubility of strontium-substituted apatite by solid titration. Acta Bio 5:1678-1685 
21. Schrooten I, Cabrera W, Goodman WG, Dauwe S, Lamberts LV, Marynissen R, Dorrine W, De Broe ME, D'Haese PC (1998) Strontium causes osteomalacia in chronic renal failure rats. Kidney Int 54:448-456

22. D'Haese PC, Schrooten I, Goodman WG, Cabrera WE, Lamberts LV, Elseviers MM, Couttenye MM, De Broe ME (2000) Increased bone strontium levels in haemodialysis patients with osteomalacia. Kidney Int 57:1107-1114

23. Boivin G, Deloffre P, Perrat B, Panczer G, Boudeulle M, Mauras Y, Allain P, Tsouderos Y, Meunier PJ (1996) Strontium distribution and interactions with bone mineral in monkey iliac bone after strontium salt (S 12911). J Bone Miner Res 11:1302-1311

24. Orriss IR, Utting JC, Brandao-Burch A, Colston K, Grubb BR, Burnstock G, Arnett TR (2007) Extracellular nucleotides block bone mineralization in vitro: evidence for dual inhibitory mechanisms involving both P2Y2 receptors and pyrophosphate. Endocrinology 148:4208-4216

25. Orriss IR, Taylor SE, Arnett TR (2012) Rat osteoblast cultures. Methods Mol Biol 816:31-41

26. Patel JJ, Utting JC, Key ML, Orriss IR, Taylor SE, Whatling P, Arnett TR (2012) Hypothermia inhibits osteoblast differentiation and bone formation but stimulates osteoclastogenesis. Exp Cell Res 318:2237-2244

27. Orriss IR, Key ML, Hajjawi MO, Arnett TR (2013) Extracellular ATP released by osteoblasts is a key local inhibitor of bone mineralisation. PLoS One 8(7):e69057

28. Karsdal MA, Bay-Jensen AC, Lories RJ, Abramson S, Spector T, Pastoureau P, Christiansen C, Attur M, Henriksen K, Goldring SR, Kraus V (2014) The coupling of bone and cartilage turnover in osteoarthritis: opportunities for bone antiresorptives and anabolics as potential treatments? Ann Rheum Dis 73:336-348

29. Verberckmoes SC, De Broe ME, D'Haese PC (2003) Dosedependent effects of strontium on osteoblast function and mineralization. Kidney Int 64:534-543

30. Barbara A, Delannoy P, Denis BG, Marie PJ (2004) Normal matrix mineralization induced by strontium ranelate in MC3T3-E1 osteogenic cells. Metabolism 53:532-537

31. Verberckmoes SC, Behets GJ, Oste L, Bervoets AR, Lamberts LV, Drakopoulos M, Somogyi A, Cool P, Dorrine W, De Broe
ME, D'Haese PC (2004) Effects of strontium on the physicochemical characteristics of hydroxyapatite. Calcif Tissue Int 75:405-415

32. Marie PJ (2008) Effective doses for strontium ranelate. Osteoporos Int 19:1813

33. Meunier PJ, Roux C, Seeman E, Ortolani S, Badurski JE, Spector TD, Cannata J, Balogh A, Lemmel EM, Pors-Nielsen S, Rizzoli R, Genant HK, Reginster JY (2004) The effects of strontium ranelate on the risk of vertebral fracture in women with postmenopausal osteoporosis. N Engl J Med 350:459-468

34. Blake GM, Fogelman I (2007) Effect of bone strontium on BMD measurements. J Clin Densitom 10:34-38

35. Schrooten I, Behets GJ, Cabrera WE, Vercauteren SR, Lamberts LV, Verberckmoes SC, Bervoets AJ, Dams G, Goodman WG, De Broe ME, D'Haese PC (2003) Dosedependent effects of strontium on bone of chronic renal failure rats. Kidney Int 63:927-935

36. Schrooten I, Elseviers MM, Lamberts LV, De Broe ME, D'Haese PC (1999) Increased serum strontium levels in dialysis patients: an epidemiological survey. Kidney Int 56:18861892

37. Zioupos P, Currey JD, Casinos A (2000) Exploring the effects of hypermineralisation in bone tissue by using an extreme biological example. Connect Tissue Res 41:229-248

38. Reginster JY, Badurski J, Bellamy N, Bensen W, Chapurlat R, Chevalier X, Christiansen C, Genant H, Navarro F, Nasonov E, Sambrook PN, Spector TD, Cooper C (2013) Efficacy and safety of strontium ranelate in the treatment of knee osteoarthritis: results of a double-blind, randomised placebo-controlled trial. Ann Rheum Dis 72:179-186

39. Bruyere O, Delferriere D, Roux C, Wark JD, Spector T, Devogelaer JP (2008) Effects of strontium ranelate on spinal osteoarthritis progression. Ann Rheum Dis 67:335-9

40. Atkins GJ, Findlay DM (2012) Osteocyte regulation of bone mineral: a little give and take. Osteoporos Int 23:2067-2079

41. Donneau AF, Reginster JY (2014) Cardiovascular safety of strontium ranelate: real-life assessment in clinical practice. Osteoporos Int 25: 397-398 